\title{
РОМАН ДОЦЯ ТАМАРИ ГОРІХА ЗЕРНЯ: СТРАТЕГІЇ ТВОРЕННЯ ЕФЕКТУ СПІВПРИЧЕТНОСТІ
}

\author{
ТЕТЯНА ГРЕБЕНЮК \\ Запорізький державний медичний університет, Запоріжжя - Україна \\ s_gtv@ukr.net; ORCID: 0000-0003-1910-5411 \\ POWIEŚĆ TAMARY HORICHA ZERNIA DOCIA: \\ STRATEGIE TWORZENIA EFEKTU WSPÓŁUDZIAŁU \\ TETIANA HREBENIUK \\ Zaporoski Państwowy Uniwersytet Medyczny, Zaporoże — Ukraina
}

\begin{abstract}
STRESZCZENIE. Artykuł rozważa strategie narracyjne tworzenia efektu zaangażowania czytelnika w doświadczenia życiowe postaci w powieści Tamary Horichy Zerni Docia, poświęconej aktualnym problemom wojny na wschodzie Ukrainy. Teoretyczne podstawy pracy oparte są na zaproponowanej przez Monikę Fludernik w badaniach narratologii kognitywnej koncepcji 'doświadczeniowości' ('experientiality'), związanej z reprezentacją świadomości bohatera lub reprezentacją roli mówcy w utworze. Głównymi strategiami tworzenia ‘doświadczeniowości’ w powieści Docia są mimetyczność w odtwarzaniu realiów regionu, manipulowanie kategorią tożsamości lokalnej i żywa emocjonalna narracja dzieła. Najczęstszymi wzorcami wyrażania emocji w powieści są depersonalizacja, ukazanie reakcji ciała na wydarzenia oraz elementy demaskujące inwektywne dygresje autorskie w dyskursie artystycznym.
\end{abstract}

Słowa kluczowe: 'doświadczeniowość' ('experientiality'), strategia narracyjna, narratologia kognitywna, mimetyczność, tożsamość lokalna, wzorce wyrażania emocji

\section{THE NOVEL BY TAMARA HORIHA ZERNIA DOTSYA: STRATEGIES OF CREATING THE EFFECT OF COOPERATION}

\author{
TETIANA HREBENIUK
}

Zaporizhzhia State Medical University, Zaporizhzhia - Ukraine 
ABSTRACT. The article considers narrative strategies of the creation of the effect of the reader's involvement in the protagonist's life experience in Tamara Horiha Zernia's novel Dotsya, which is devoted to the important problem of today - the war on the east of Ukraine. The theoretical framework of the study is based on Monika Fludernik's cognitive-narratological conception of experientiality referring to the idea of the reader's familiarization with a character's experience by narrative means. Three strategies of creating the experientiality in this novel are seen as the most important: mimetism while reflecting the region realities, manipulation by the category of local identity, and vivid emotionality of the novel's narrative. The protagonist's depersonalization, the display of corporal reactions and the inclusion of invective digressions into the fictional discourse are considered as prevailing patterns of emotional expression.

Keywords: experientiality, narrative strategy, cognitive narratology, mimetism, local identity, patterns of the emotion expression.

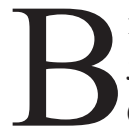
ійськові події на сході України здобули на сьогодні своє художнє втілення у багатьох художньо-літературних і документальних текстах. Серед найвідоміших творів на цю тематику - Маріупольський проиес Галини Вдовиченко, Інтернат Сергія Жадана, Укри Богдана Жолдака, Аероnорт Сергія Лойка, Довгі часи Володимира Рафєєнка, Доия Тамари Горіха Зерня, Чорне сонце Василя Шкляра та багато інших. Ще у 2018 році книжкова оглядач Ганна Скоріна уклала перелік книжок, присвячених війні на сході України, який налічував 147 художніх прозових видань. Відповідно, надзвичайно актуальними є спроби літературознавців (а також філософів, істориків, соціологів, політологів) науково осмислити природу цих творів, проаналізувати їх у найширших суспільно-політичних контекстах, дати їм оцінку не тільки з погляду їх художньої вартості, а й із погляду їх відповідності сучасним реаліям, адекватності передачі в них людського досвіду.

Категорією, яка багато в чому прояснює як підгрунтя самої російсько-української війни, так і специфіку художнього втілення їі подій, виступає категорія ідентичності — 'гібридної', 'розмитої', ‘помежової' локальної ідентичності мешканців Донбасу. Ярослав Поліщук у своїй розвідці з проблеми локальної ідентичності Донбасу так окреслює їі природу: „Мабуть, одним із ключових чинників триваючої кризи локальної ідентичності Донбасу слід визнати брак традиції, який зумовлює розгубленість, дезорієнтованість та непослідовність мешканців регіону у прийнятті важливих рішень. Відсутність традиції, [...], породжує страх і непевність у сприйнятті нинішньої ситуації" [Поліщук 2018: 258]. Можна сказати, що ідентичність Донбасу є надзвичайно специфічним ментальним утворенням, яке постало в унікальних історичних умовах, і тому для мешканців інших регіонів України (а тим більше для світової спільноти) осягнення іiі природи становить певну когнітивну проблему. Звідси оце наболіле й заяложене ЗМІ прагнення “зрозуміти Донбас”, що, гіпотетично, сприятиме завершенню війни. 
Далеко не всі українські художні твори, присвячені проблемі війни на Донбасі, мають на меті донести до читача нюанси ідентичнісної інакшості мешканців регіону, а з-посеред тих, котрі таки спрямовані на це, не всі досягають такої мети. У цьому контексті особливу увагу привертає твір, надзвичайну художню (міметичну) переконливість якого засвідчують численні критичні рецензії й читацькі відгуки, - роман Тамари Горіха Зерня Доия. Оксана Забужко відзначає як важливе досягнення авторки вміння показати читачеві створену цією війною „нову героїню, якої вже не скасуєш скептичним «вивсьоврьотє»: героїню, яка навчилась не тільки діяти, а й говорити (i писати!) за себе сама. і цій героїні просто не залежить уже на тому, чи віритимуть їй боягузи, дезертири, українські журналісти й представники європейських місій” [Забужко 2019]. Ростислав Семків характеризує роман як „пронизливий, емоційно напружений, динамічний текст із мозаїчною структурою" [Семків 2020].

Авторка твору свідомо ставить перед собою завдання „змусити максимальну кількість людей, яка купить цю книгу, опинитися у шкурі людей, які жили в той час на Донбасі, пропустити через себе, подивитися своїми очима на ці подіі” [Куренная 2019]. Для досягнення цього завдання Тамара Горіха Зерня вдається до набору характерних наративних стратегій, оприявнюваних на всіх рівнях побудови оповіді.

Метою цієї статті $\epsilon$ аналіз наративних стратегій, завдяки яким досягається ефект наближення читача до життєвого досвіду персонажа, відчуття співпричетності до нього. Теоретичну концептуалізацію цей ефект здобув у понятті 'experientiality', запровадженому в межах когнітивно-наратологічних студій Монікою Флудернік у іiі праці 1996 року Towards a 'Natural' Narratology. Дослідниця характеризує експеренційність як „квазі-міметичне відтворення «досвіду реального життя»" [Fludernik 1996] й розглядає іiї в досить широкому екзистенційно-гуманістичному контексті репрезентації свідомості: „вона також співвідноситься з відтворенням свідомості або з репрезентацією ролі мовця. Експеренційність, як і все інше в наративі, відображає когнітивну схему втілення, котра стосується людського буття й людських турбот" [Fludernik 1996: 9]. Такий кут зору дає Самуелю Калебу Ві підстави твердити, що Моніка Флудернік у своєму підході до наративності ставить у пріоритет насамперед „феноменологічний досвід читання й існування через наратив" [Wee 2019: 96], на противагу, наприклад, 'акційним' підходам до неї, в яких визначальною $є$ дія, сюжетна оповідь. Зіставляючи підхід дослідниці до наративності, наприклад, із підходом Вольфа Шміда, для якого однією з їі

\footnotetext{
${ }^{1}$ Переклад аналізованого поняття українською мовою становить певну проблему. Олег Собчук [Собчук 2012: 109] вживає на його означення термін 'досвідченість'. Але задля більшої точності тлумачення й уникнення зайвих конотацій натомість пропонуємо термін 'експеренційність'
} 
головних критеріальних ознак є подієвість [Шмід 2003], відзначимо, що для М. Флудернік такою ознакою є оприявнення людського досвіду у свідомості реципієнта. Попри те, що механізм передачі через наратив досвіду Іншого $€$ об'єктом уваги й інших наратологів ${ }^{2}$, саме концепція М. Флудернік $\epsilon$, на наш погляд, найадекватнішою для аналізу наративних механізмів передачі досвіду буття на життєвому помежів 'i, в 'сірій зоні' простору неоголошеної війни.

Першою, найочевиднішою стратегісю творення експеренційності аналізованого роману є його виразна міметичність, майже фотографічне відтворення в ньому ландшафтних, історичних, політичних реалій регіону. Недаремно лейтмотивним у критичному дискурсі твору є твердження про потужність документального первня у його художній структурі. Оксана Забужко розглядає роман Тамари Горіха Зерня як вияв західного жанру 'faction', у якому поєднуються художня й документальна основи, й зазначає, що цьому жанрові „належатиме мейнстрим у добу наростаючої інформаційної перенасичености — коли не треба, ради Бога, не треба нам нічого більше вигадувати й додавати до реальности, аби зробити ії захопливішою, а дайте хоч якось упоратися з тою, що є...” [Забужко 2019].

Катажина Якубовська-Кравчик, розмірковуючи щодо функцій згадуваної фактографічності в українській літературі про Майдан і війну на сході України, пише, що документальний (зокрема щоденниковий) первень прочитується тут як форма терапії й спосіб упорядкування впорядкування окремих випадків [Jakubowska-Krawczyk 2017: 266]. Можемо зазначити, що терапевтичний ефект при цьому поширюється й на автора, який вербалізує свій біль, і на читачів, які знаходять у тексті вербалізоване автором вираження своєї травми.

Читацькою реакцією на міметизм, документальний струмінь роману Доия $\epsilon$ підвищення загальної довіри до оповідуваного у творі. Про це свідчить, наприклад, читацька рецензія Інни Долгушиної на роман у Інтернет-виданні $B B C$ News. Україна. Авторка рецензії впізнає описану у творі церкву в Карлівці, де вона хрестила власну дитину. Більше того, ії враження від краси цієї церкви конгеніальне враженню героїні-нараторки, й це стає однією з підстав для граничної довіри до авторського слова в романі. „Вона буквально перенесла мене в минуле життя” [Долгушина 2019], — так характеризує I. Долгушина ефект від документальної фактографічності й щирості оповіді в книзі.

На сторінках роману “внутрішнім поглядом” фокалізовано загальновідомі недавні події життя Донбасу: аварія на шахті імені Засядька 2007 року, події Майдану й захоплення держустанов у Донецьку, відлуння катастрофи Boeing 7772014 року тощо. У такий спосіб кожен читач-нерезидент Донбасу здобуває можливість зіставити цю 'внутрішню фокалізацію' із власним

\footnotetext{
${ }^{2}$ Наприклад, Девіда Германа, який адаптує для цього проблемного поля термін 'qualia' [Herman 2009], або Алана Палмера, який вживає термін 'experientiality' поруч із його контекстуальним синонімом 'fictional mental functioning' [Palmer 2004].
} 
поглядом на події, сформованим переважно ЗМІ, й відчути біль безсилля проукраїнських мешканців регіону. Також значно підвищує переконливість оповіді, суттєво міметизуючи іiі, художнє оформлення книги - включення до видання шокуючих і відвертих фотографій із архіву Дмитра Муравського та фото замисленого жіночого погляду для обкладинки (авторства Анастасії Зюркалової).

Сама Тамара Горіха Зерня прагнула ефекту реалістичності, спеціально збираючи, крім офіційної інформації й даних, доступних їй від власних знайомих, інші джерела. Так, авторка роману цілеспрямовано переглядала відеоролики на YouTube, численні міські форуми, використовувала свідчення волонтерки Наталі, яка стала прототипом образу протагоністки. При читанні роману виникає враження, що мультимедійність у пошуках інформації героями твору (Ми тоді всі втекли в онлайн. Навіть ті, хто раніше уявлення не мав про соиіальні мережі... [Тамара Горіха Зерня 2019: 75]), а згодом і в боротьбі 3 ворогом, є своєрідним фрактальним відображенням мультимедійності авторських студій при роботі над романом, завдяки яким, до речі екперенційність тексту також посилюється ${ }^{3}$. У передмові Bid автора читаємо, що Доия $\epsilon$ „документальним твором настільки, наскільки це можливо для художнього твору. Кожен діалог чи епізод відбувся у реальному житті, хай навіть не в тому місці і не в той час" [Тамара Горіха Зерня 2019: 2].

Проте авторка роману відходить від надмірної індивідуалізації описуваного досвіду, аби продемонструвати його типовість для ‘сірої зони' Донбасу. і тут варто окреслити другу важливу наративну стратегію творення експеренційності оповіді твору — маніпуляції локальною ідентичністю, а саме універсальність описуваного досвіду для мешканців регіону й водночас зрозумілість цього досвіду для носіїв ширшої, національної ідентичності. Саме тому, за словами письменниці, героїню твору навіть не наділено власним іменем - тільки прізвиськом 'Ельф'. Першоособова форма оповіді у романі $\epsilon$ стратегічно важливою для авторки: „Це я спеціально так зробила для того, щоб ' $Я$ ' легше злилося із ' $Я$ ' читача. Це один із таких прийомів, який мені здався важливим для того, щоб спростити людині перехід через цей місток” [Куренная 2019].

Задля побудови “містка" між свідомістю, світовідчуттям мешканців Донбасу та інших регіонів України авторка наділяє героїню-нараторку твору подвійною ідентичністю. Хоча раннє дитинство їі пройшло в Донецьку, виросла вона на Рівненщині. Коли приїздить до Донецька вже після закінчення школи,

\footnotetext{
${ }^{3}$ Марія Макела на прикладі аналізу впливу мережі Facebook доводить, що соцмережі надають викладеним у них оповідям додаткової експеренційності вже за рахунок власного функціоналу як платформи для поділу досвідом. Так, наприклад, указівка на локацію, де перебуває користувач або що він їсть, максимізує співпричетність до його досвіду [Mäkelä 2019: 163].
} 
сформованою особистістю, то залишається тут наполовину чужою, бачить реалії Донбасу дещо 'одивненими' через свою нетутешність. Ярослав Поліщук, розглядаючи проблему донбаської ідентичності на прикладі роману Олександри Іванюк $A м о p(m) e$, протагоністка якого - іноземка, теж чужа на Донбасі, зазначає виграшність подібного прийому, який дає можливість відстороненої, об'єктивної оцінки помежового краю [Поліщук 2019: 169]. Зазначимо, що в романі Доия інтегрованість героїні значно глибша, вона грунтується на більшій кількості позитивних людських зв'язків, які встановлює протагоністка у процесі дії твору. I, врешті, Тамара Горіха Зерня афористично пояснює: Дім, у якому ти плакала, уже ніколи не буде зовсім чужим [Тамара Горіха Зерня 2019: 15]. Тож героїня твору таки залишається носієм досвіду мешканців Донбасу, принаймні, тієї частини, якій не все одно, що відбувається на їхній землі.

Крім того, авторка виходить у творі на універсальні виміри ідентичності, свідомо чи несвідомо міфологізуючи центральний образ. Христологічні аналогії до образу протагоністки активно проводить у своїй рецензії на Доцюю Тетяна Петренко [Петренко 2020]. Згадуючи походження Ельфа від згодом таємничо зниклої матері-мисткині на ім'я Марія, целібат як життєве кредо героїні, наявність у неї паранормальних здібностей, харизми й групи власних 'апостолів', рецензентка іронічно резюмує: „Доця не просто Ісус у спідниці. Вона та їі матір - жіноча альтернатива Богу і його Сину. а отже, перед нами не новий, а надновий заповіт, який дає Донбасу надію" [Петренко 2020].

Згадаємо також амбівалентний образ вогню, який супроводжує важливі моменти життя героїні: вогнище на місці зникнення матері й підпал хати після цього, пожежа, яку вона гасила разом з Романом, коли з ним познайомилась, перебування на межі смерті від вибуху й вогню, коли навіть волосся іiї згоріло тощо, вибухи боєприпасів зумовлюють загибель близьких героїні людей. Тамарі Горіха Зерня вдається - через маніпулювання різними виявами ідентичності - закласти основи експеренційності оповіді, уможливити розуміння досвіду Іншого для читача.

Третьою стратегісю реалізації експеренційності романного наративу $\epsilon$ вираження на сторінках твору емоцій нараторки. Суттєвою ознакою прози про війну на сході України загалом і роману Доия зокрема є іiі яскрава емоційність. Це неодноразово зазначали рецензенти твору [див, наприклад: Коцарев 2020]. Емоційний складник $є$ надзвичайно важливим для процесу творення експеренційності, адже чужий досвід найкраще освоюється через почуттєву сферу — як стає своїм уже згадуваний дім, „у якому ти плакала”. Як зазначають Реймонд Мар та співавтори, досліджуючи вплив емоційних чинників у процесі читання художньої літератури та після нього, емоції від твору викликають у читача такі ефекти, як симпатія, ідентифікація, емпатія й емоційне полегшення, а вже після завершення читання зумовлюють зміни 
в когнітивній обробці інформації та трансформацію особистості ${ }^{4}$ [Mar, Oatley, Djikic, Mullin 2011]. Дослідники проводять межу між сприйманням документальної прози, яка має на меті інформувати, й художніх творів, які спрямовані на те, щоб зворушити читача, передати досвід, мають своїм осередком саме емоції [Mar, Oatley, Djikic, Mullin 2011: 822].

Такі оцінки спонукають до рефлексії над роллю документального первня в романі, та схиляють до висновку про перевагу первня художнього. Адже соціально-історична інформація, подана в романі, $є$ вже відомою читачам, а от досвід, переживання подій, забарвлене емоційним ставленням до них героїні, безперечно, зворушують, заторкують почуття читача за законами фікційної прози. Проте документальний складник суттєво впливає на адаптацію в романі законів побудови наративу. Мейр Стерберг вважає, що універсальними рушіями наративу є емоції саспенсу, цікавості й здивування [Sternberg 2001]. Оскільки історико-політична канва подій на Донбасі читачеві вже відома, peсурси цікавості й здивування при сприйманні тексту дещо обмежені - здебільшого вони мають вияв щодо приватного досвіду героїні. а от саспенс (хоча він також стосується подій приватного досвіду) завдяки обізнаності читача з суспільно-політичним тлом тільки загострюється. Реципієнтові тексту добре відомо, наскільки реальними для конкретних персонажів є загрози втрати свободи, каліцтва, смерті. Можна сказати, що позатекстові джерела знань про історико-політичне тло подій оповіді ефективно 'спрацьовують' на посилення емоційності сприймання.

Взагалі, когнітивний аспект формування емоційності, наративної емпатії у творах про війну на Донбасі вартий особливої уваги в контексті злиття інтра- й екстранаративних чинників їхнього формування. Читач, який береться за художню книгу цієї тематики, майже завжди внутрішньо підготовлений до сприймання тексту, бо вже має певний інформаційний бекграунд, почерпнутий із власного досвіду, досвіду родини/друзів/знайомих, із засобів масової інформації, чуток. Тож цікавою для нього на сьогодні $є$ саме та унікально фікційна лінія оповіді, яка дає новий кут зору, оригінальну художню інтерпретацію подій, досвід, емоцію. і при формуванні емоційної реакції читача несвідомим посилювачем її гостроти виступає ця попередня поінформованість про трагізм, шокуючу жорстокість і несправедливість оповідуваних подій.

Цей ефект, безумовно, присутній і в романі Тамари Горіха Зерня. На сторінках твору часто подаються описи станів страху, шоку, обурення, гніву, ненависті протагоністки й інших персонажів. Зображення викликаного ними людського плачу є наскрізним у романі: довго й гірко плаче баба героїні, коли бачить по телевізору початок кровопролиття на Майдані, плачуть пасажири

\footnotetext{
${ }^{4}$ Подібну думку про зміни в початковій «картині світу» реципієнта під впливом читання твору з високим рівнем експеренційності знаходимо й у Марка Караччіоло [Caracciolo 2014: 49-50].
} 
останнього поїзда з Донецька, коли він приїхав до Дніпра, “виє на грудях" у нараторки сусідка Людмила, у якої зник безвісти чоловік тощо.

Проте для передачі найгостріших людських емоцій авторка широко використовує два найбільш популярні патерни: деперсоналізація, враження, що “це відбувається не зі мною”, й тілесні вияви емоцій. Наприклад, коли героїня спостерігає штурм “ополченцями” будівлі обладміністрації, вона так описує власні відчуття: Ми провалюємося у кролячу нору. Все, на що можна було опертися, розсипається під руками на порох. Тут реальність розходиться із здоровим глуздом, я заплюшую очі і вдаю, щяо мене немає. Ущипніть мене хто-небудь! Я равлик, я декорачія, я скіфська баба [...] Ніколи в житті я не почувалася такою самотньою і безпорадною [Тамара Горіха Зерня 2019: 52]. У моменти найгострішого дисонансу між звичним, повсякденним людським буттям і шокуючими проявами жорстокості героїню супроводжує враження 'несправжності', 'загіпнотизованості', 'сну', в якому вона перебуває. Можна розглядати цей патерн як універсальний ‘мінус-прийом’ у зображенні емоційного стану героїні, який водночас не передає нічого й передає забагато, адже кожен читач може заповнити його власними досвідами жаху й шоку, “приміряти на себе” цей стан.

Другим патерном передачі найгостріших емоцій у тексті $є$ показ тілесних реакцій на подію в рамках традиційної для роману першоособової нарації. Наприклад, після нищівного обстрілу з вертольоту російської армійської вантажівки протагоністка відчуває, що не може дихати, коли до Донецька заходить колона російської техніки і героїня, приймаючи ії за українське військо, трохи не вигукує „Слава Україні!” — iї “вивертає жовчю Романові під ноги” [Тамара Горіха Зерня 2019: 175]; вона втрачає свідомість, коли чує постріли біля двору Романа й підозрює, що його й Тетяну вбито, у неї 'віднімаються ноги'. Можна сказати, що цей спосіб вираження емоцій, попри свою позапсихологічну природу, є дієвою універсальною матрицею, яка допомагає 'достукатися’ до емоційної сфери читача через його власний досвід переживання травматичних подій.

Варто також відзначити, що важливим чинником емоційного впливу роману Доцяя на сучасників $€$ публіцистична інвективність окремих фрагментів його дискурсу. Деякі періоди тексту, вириваючись поза рамки художності (або й навіть документальності), виражають громадянську позицію читачів, влучно вербалізовані авторкою гнів, образу, ненависть до агресора. Висловлені від особи нараторки роздуми накладаються на вистраждані багатьма переконання: Не знайдеться слів, щоб описати біль і приниження, з яким ми вступили у війну. Це відчуття безпомічного розпачу, коли ненавчені, невмілі, неготові чоловіки падали підкошеними, не розуміючи, звідки стріляють. Цю глибину потрясіння, коли ми побачили, щуо свої ж командири праџюють на ворога [Тамара Горіха Зерня 2019: 78]. 
Так само конгеніально для патріотично налаштованого читача сприймається й гнівне звернення нараторки (авторки?) до Василя Стуса як одного з патріотів-носіїв донбаської ідентичності: Засуньте в дупу свою „хату скраю”. Якби я побачила Стуса, я б йому сказала - убивай! Вирви очі, викуси кадик, умри в бою, умри так, щоб вони тебе розтерзали двадиять на одного, але до скону сиялися б у ліжко від самої згадки про тебе [...] Навіть якщо довкола тебе немає Украйни, навіть якщо там пустка і лід, навіть якщо там тьма єгипетська, у тобі самому України стане з головою, бо Україна - ие ти [Тамара Горіха Зерня 2019: 177].

Отже, найпоширенішими патернами вираження емоцій у романі Тамари Горіха Зерня Доия можемо вважати стан деперсоналізації протагоністки у критичні й небезпечні моменти, показ реакцій на шокуючі події через призму тілесних проявів і вкраплення викривально-інвективних відступів у художній дискурс. Серед обраних авторкою наративних стратегій творення експеренційності в романі найпродуктивнішими є міметичність при відтворенні в ньому реалій регіону, маніпулювання категорією локальної ідентичності (коли свій вияв здобуває то регіональний, то національний іï первень) і яскрава емоційність оповіді твору.

\section{Список використаної літератури}

Долгушина I., Дім, у якому ти плакала, уже ніколи не буде зовсім чужим, [в:] Електронний pecypc: https://www.bbc.com/ukrainian/features-50287695 (04.11.2019).

Забужко О., У війни - жіноче обличчя, [в:] Електронний ресурс: https://spektrnews.in.ua/ news/u-v-yni--- zh-noche-oblichchya---oksana-zabuzhko/82764 (17.07.2019).

Коцарев О., „Доцяя”: пригодницький роман про війну, який „проситься” в серіал, [в:] Електронний ресурс: https://texty.org.ua/articles/99927/Doca_prygodnyckyj_roman_pro_ vijnu_jakyj_prosyts a-99927/ (17.02.2020).

Куренная Д., ,,Ми з моєю героїнею свідомо переӥхали в Донецььк”- -авторка книги року BВC Тамара Горіха Зерня, [в:] Електронний ресурс: https://www.radiosvoboda.org/ $\mathrm{a} / 30324618 . \mathrm{html}$ (13.12.2019).

Петренко Т., Iсусе, синку: „Доия” як месія з Донбасу, [в:] Електронний ресурс: http://www. chytomo.com/isuse-synku-dotsia-iak-mesiia-z-donbasu/ (26.02.2020).

Поліщук Я., Досвід локальної ідентичності, [в:] „Studia Ukrainica Posnaniensia”, 2018, nr VI, c. 257-267.

Поліщук Я., Метафорика Донбасу, [в:] „Studia Ukrainica Posnaniensia”, 2019, zeszyt VII/2, c. 259-267.

Ростислав Семків: Нормально українська література востаннє функиіонувала за гетьмана Івана Мазепи. Інтерв 'ю. Розмовляв I. Прокопенко, [в:] Електронний ресурс: https:// rozmova.wordpress.com/2020/02/06/rostyslav-semkiv-4/ (06.02.2020). 
Собчук О.В., Переосмислення понять наративності, персонажа і фокалізації в сучасній когнітивній наратологї, [в:] „Магістеріум. Літературознавчі студії”, 2012, № 48, c. $108-113$.

Шмид В., Нарратология, Москва 2003.

Caracciolo M., The Experientiality of Narrative: An Enactivist Approach, Berlin 2014.

Fludernik M., Towards a 'Natural' Narratology, London 1996.

Herman D., Basic Elements of Narrative, Chichester 2009.

Jakubowska-Krawczyk K., Тема майдану і АТО в украйнській і польській літературі. Різноманітність жанрів, [в:] „Studia Ukrainica Posnaniensia”, 2017, zeszyt 5, s. 259-267.

Mäkelä M., Literary Facebook Narratology: Experientiality, Simultaneity, Tellability, [in:] „Partial Answers: Journal of Literature and the History of Ideas”, 2019, vol. 17, No. 1, p. 159-182.

Mar R.A., Oatley K., Djikic M., Mullin J., Emotion and narrative fiction: Interactive influences before, during, and after reading, [in:] „Cognition and Emotion”, 2011, No. 25 (5), p. 818-833.

Palmer A., Fictional Minds, Lincoln 2004.

Sternberg M., How Narrativity Makes a Difference, [in:] „Narrative”, 2001, No. 9 (2), p. 115-122.

Wee S.C., Songs of 'Experientiality': Reconsidering the Relationship between Poeticity and Narrativity in Postclassical Narratology, [in:] „Word and Text A Journal of Literary Studies and Linguistics", 2019, No. IX, p. 93-106.

\section{Список використаних джерел}

Тамара Горіха Зерня, Доия. Художнє видання, Київ 2019.

\section{Spysok vykorystanoi literatury [References]}

Dolhushyna I., Dim, u yakomu ty plakala, uzhe nikoly ne bude zovsim chuzhym [The House where you Have Cried Will Never be Alien], [v:] Elektronnyi resurs: https://www.bbc.com/ ukrainian/features-50287695 (04.11.2019).

Zabuzhko O., U viiny — zhinoche oblychchia [War Has a Woman'Face], [v:] Elektronnyi resurs: https://spektrnews.in.ua/news/u-v-yni--- zh-noche-oblichchya---oksana-zabuzhko/82764 (17.07.2019).

Kotsarev O., ,,Dotsia”: pryhodnytskyi roman pro viinu, yakyi ,prosytsia”v serial [,Dotsia”: an Adventure Novel about War Yearning for Series], [v:] Elektronnyi resurs: https://texty.org.ua/ articles/99927/Doca_prygodnyckyj_roman_pro_vijnu_jakyj_prosytsa-99927/(17.02.2020).

Kurennaia D., ,, My z moieiu heroineiu svidomo pereikhaly v Donetsk”- avtorka knyhy roku VVS Tamara Horikha Zernia [,,I and my Protagonist Consciously Moved to Donetsk” - an Author of the BBC Book Prize Tamara Horikha Zernia], [v:] Elektronnyi resurs: https:// www.radiosvoboda.org/a/30324618.html (13.12.2019). 
Petrenko T., Isuse, synku: „Dotsia” yak mesiia z Donbasu [Jesus, Sonny: „Dotsia” as a Donbass Messiah], [v:] Elektronnyi resurs: http://www.chytomo.com/isuse-synku-dotsia-iak-mesiiaz-donbasu/ (26.02.2020).

Polishchuk Ya., Dosvid lokalnoi identychnosti [An Experience of the Local Identity], [v:] „Studia Ukrainica Posnaniensia", 2018, zeszyt VI, s. 257-267.

Polishchuk Ya., Metaforyka Donbasu [Metaphors of Donbass], [v:] „Studia Ukrainica Posnaniensia", 2019, zeszyt VII/2, s. 259-267

Rostyslav Semkiv: Normalno ukrainska literatura vostannie funktsionuvala za hetmana Ivana Mazepy. Interviu. Rozmovliav I. Prokopenko [Ukrainian Literature Last Functioned Nornally under Hetman Ivan Mazepa's Rule. Interview. Talked I. Prokopenko], [v:] Elektronnyi resurs: https://rozmova.wordpress.com/2020/02/06/rostyslav-semkiv-4/ (06.02.2020).

Sobchuk O.V., Pereosmyslennia poniat naratyvnosti, personazha i fokalizatsii v suchasnii kohnityvnii naratolohii [Reconsideration of the Notions of Narrativity, Character, and Focalization in Contemporary Cognitive Narratology], [v:] Mahisterium. Literaturoznavchi studii, 2012, nr 48, s. 108-113.

Shmyd V., Narratolohyia, [Narratology], Moskva 2003.

Caracciolo M., The Experientiality of Narrative: An Enactivist Approach, Berlin 2014.

Fludernik M., Towards a 'Natural' Narratology, London 1996.

Herman D., Basic Elements of Narrative, Chichester 2009.

Jakubowska-Krawczyk K., Tema maidanu i ATO v ukrainskii i polskii literaturi. Riznomanitnist zhanriv [Maidan and ATO Themes in Ukrainian and Polish Fiction. Genre Diversity], [v:] „Studia Ukrainica Posnaniensia”, 2017, nr 5, s. 259-267.

Mäkelä M., Literary Facebook Narratology: Experientiality, Simultaneity, Tellability, [in:] „Partial Answers: Journal of Literature and the History of Ideas”, 2019, vol. 17, No. 1, p. $159-182$.

Mar R.A., Oatley K., Djikic M., Mullin J., Emotion and narrative fiction: Interactive influences before, during, and after reading,. [in:] „Cognition and Emotion”, 2011, No. 25 (5), p. 818 833.

Palmer A., Fictional Minds, Lincoln 2004.

Sternberg M., How Narrativity Makes a Difference, [in:] „Narrative”, 2001, No. 9 (2), p. 115 122.

Wee S.C., Songs of 'Experientiality': Reconsidering the Relationship between Poeticity and Narrativity in Postclassical Narratology, [in:] „Word and Text A Journal of Literary Studies and Linguistics", 2019, No. IX, p. 93-106.

\section{Spysok vykorystanykh dzherel \\ [References]}

Tamara Horikha Zernia, Dotsia [The Daughter], Khudozhnie vydannia, Kyiv 2019. 